\title{
特集「少子高齢時代の交通インフラ」にあたって \\ Transport Infrastructure in aged society with a low birth rate
}

Masayuki NAKAGAWA

今後少子高齢化が本格的に進展することで, 交通需要も質及び量, 2 つの側面で大きく変化す ることが予想される。まず，自らの力だけでは移動することが困難な人口が増加する。この傾向 は交通インフラのバリアフリー化や新しいタイプの交通手段への要請を増大させる。もう一つは, 都市の郊外部や地方部を中心に公共交通機関の維持可能性が低下することだ。この傾向により, 地域独占を認めて内部補助によって地域交通を維持してきた従来の交通政策からの転換により拍 車がかかる可能性がある。

このような交通需要に関する需要変化が予想される中で, 公共部門の財政状況の逼迫性はより 深刻なものになろうとしている。少子高齢化は税源に大きな影響を与えるだけでなく，社会保障 を通じた歳出の増大をもたらすため, 交通インフラの今後の方向性は財政状況を十分に踏まえた ものとすることが必須だろう。この特集においてはまず，これからの高速道路，鉄道，港湾，空 港などの交通インフラの整備に，どのようなスタンスで臨むべきかを議論する。特に，東日本大 震災で破壊されてしまった東北地方のインフラの復旧をいかに進めるべきか, 先般政府において 決定された整備新幹線の凍結区間の再開をどのように評価するか，という二つのトピックを取り 上げて議論を深める。

具体的には赤井伸郎氏に, 道路, 鉄道, 港湾, 空港など交通政策全般のここ数年の動向の評価 を経済学の立場から議論して頂いた。

その上で, 奥村誠氏及び河野達仁氏に, 経済学的な立場から東日本大震災被災地を念頭に置いて, 人口減少・高齢化地域における交通システムを論じて頂き, 工学の立場から谷口守氏及び森英高 氏からは，被災者の仮のくらしをどのような交通で支えるかを議論して頂いた。

井堀利宏氏からは，整備新幹線と財政に関する議論を経済学の立場から，石井晴夫氏からは, 整備新幹線の効果に関する議論を地域経営, 交通システムの立場から議論して頂いている。

特集では次に，交通需要の変化を踏まえた交通政策の将来の姿を取り上げる。根本敏則氏には， 人口減時代における道路ネットワークのあり方を, 費用負担面から議論を深めてもらった。そし て, 移動制約者の増加を踏まえた議論を集中的に行った。具体的には, 阿部名保子氏に福祉有償 運送などの高齢者の新しい移動手段に関して，現在の取り組みを踏まえた議論をして頂いている。

そして最後に，地域毎にあるべき交通政策を検討することとしよう。コンパクトシティなどの 近年提唱されている新しい都市政策では, 公共交通機関と住宅, 都市開発の一体化を提唱するなど, 従来にも増して, 都市構造と交通インフラの関係について密接な検討が求められている。この場 合交通プロパーの問題だけでなく，まちづくり，地域づくりの視点も踏まえた交通政策のあり方 に関する議論を深める。

具体的には, 唐渡広志氏に公共交通機関と都市・地域構造に関して, 経済学の立場からコンパ クトシティを取り上げてもらった。さらに, 吉田恭氏には, OECDコンパクトシティレポートを踏 まえて，公共交通機関整備とまちづくりを一体的に行っている海外事例などの紹介をして頂いた。

また岡本亮介氏には集積促進と空港, 港湾というテーマで, 大都市部における交通インフラの 整備を議論して頂き, 森山昌幸氏には地方部の公共交通機関マネジメントとして過疎, 中山間地 の交通インフラ政策を論じて頂いている。

また,この特集では総論の他は, 災害復興, 整備新幹線, 人口構造変化に対する対応，コンパ クトシティ, 地域交通政策などの共通テーマに経済学や工学, 実務など異なる立場の筆者を配置 することで，それぞれの主張の特徴が鮮明になる流れを採用している。

出版編集委員 中川雅之（日本大学経済学部） 